\title{
Synthesis of guanidinium-sulfonimide ion pairs: towards novel ionic liquid crystals
}

\author{
Martin Butschies, Manuel M. Neidhardt, Markus Mansueto, Sabine Laschat ${ }^{*}$ \\ and Stefan Tussetschläger
}

\section{Full Research Paper}

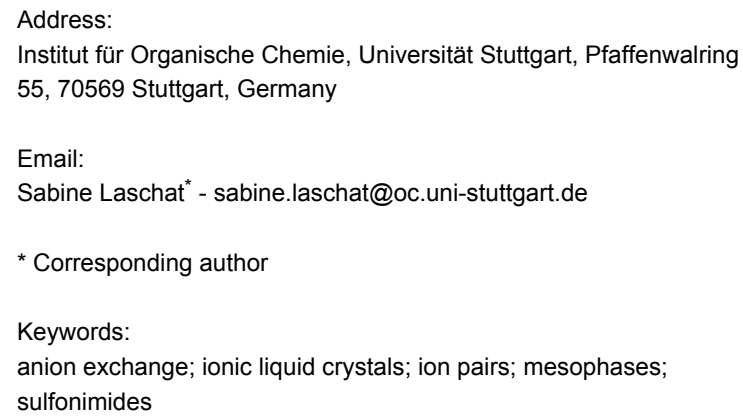

\begin{abstract}
The recently introduced concept of ionic liquid crystals (ILCs) with complementary ion pairs, consisting of both, mesogenic cation and anion, was extended from guanidinium sulfonates to guanidinium sulfonimides. In this preliminary study, the synthesis and mesomorphic properties of selected derivatives were described, which provide the first example of an ILC with the sulfonimide anion directly attached to the mesogenic unit.
\end{abstract}

\section{Introduction}

While ionic liquids, i.e., molten salts composed of either organic cation or anion (or both) with melting points far below $100{ }^{\circ} \mathrm{C}$, are extensively used as designer solvents, electrolytes for lithium ion batteries, dye-sensitized solar cells, and the electrochemical deposition of metals [1-5], the corresponding ionic liquids with thermotropic liquid-crystalline properties, i.e., ILCs, are a much younger class of compounds [6-8]. Although Heintz was the pioneer, who observed in 1854 melting and clearing transitions upon heating of magnesium myristate $[9,10]$, he did not recognize this as liquid-crystalline behavior. The first regular pyridinium ILCs were reported in 1938 by
Knight and Shaw [11,12], followed by seminal findings by Seddon and Bruce [13]. Regarding ionic liquids, sulfonimides have been used in various ways. Particularly interesting is the symmetrical bistriflimide anion [14], which leads to desirable properties such as hydrolytic stability, low viscosity or low melting points in the ionic liquids [1,4,15-19]. By using an elongated perfluoroalkyl chain at the bistriflimide anion in combination with short chain-substituted pyrrolidinium cations MacFarlane was able to induce plastic crystal phases and liquidcrystalline phases at room temperature [20]. Ion pairs consisting of perfluorosulfonylimide anions and imidazolium cations with 
short alkyl chains were studied by DesMarteau resulting in room-temperature ionic liquids [21]. In contrast, ILCs with bistriflimide anions are much less explored, because the sterically demanding anion often inhibits the formation of a mesophase [6,22]. Liquid-crystalline phases were found for viologen salts [23-28], imidazolium ILCs [29-31], pyrrolidinium ILCs [32,33] and ionic polymers [34-37]. Sulfonimides, which are directly bound to a mesogenic group, have not been described until now. We have recently described the concept of complementary ion pairs, where guanidinium sulfonate $\mathbf{1}$ with both mesogenic cation and anion displayed improved mesophase stability and increased phase widths as compared to their counterparts bearing a nonmesogenic spherical halide counterion [38,39] (Scheme 1).<smiles>CCCCCCCOc1ccc(N(C)C(N(C)C)=[N+](C)C)cc1</smiles><smiles>CCOc1ccc(S(=O)(=O)[O-])cc1</smiles>

1<smiles>[R1]N(C(N(C)C)=[N+](C)C)c1ccc(OCCC)cc1</smiles><smiles>[R]S(=O)(=O)N([O-])S(=O)(=O)c1ccc(OCC)cc1</smiles>

$$
\begin{array}{cc}
\mathrm{R}^{1}=\mathrm{CH}_{3} & \mathbf{2 a} \\
\mathrm{CH}_{3} & \mathbf{2 b} \\
\mathrm{H} & \mathbf{3 a} \\
\mathrm{H} & \mathbf{3 b}
\end{array}
$$$$
\begin{array}{r}
\mathrm{R}^{2}=\mathrm{CF}_{3} \\
\mathrm{CH}_{3} \\
\mathrm{CF}_{3} \\
\mathrm{CH}_{3}
\end{array}
$$

Scheme 1: Complementary guanidinium sulfonate 1 and guanidinium-sulfonimide ion pairs $\mathbf{2}$ and $\mathbf{3}$.

We were thus interested, whether this concept could be also used to generate the corresponding sulfonimide ion pairs $\mathbf{2}$ and 3 with mesomorphic properties. The results of this preliminary study are discussed below.

\section{Results and Discussion}

The synthesis of guanidinium-sulfonimide ion pairs commenced with the commercially available sulfonyl chloride 4 [38], which was treated with trifluoromethanesulfonamide (5a) in the presence of $\mathrm{NEt}_{3}$ following a procedure by Hesemann and Brunel [40]. Then the fluorinated sulfonimide was converted to the potassium salt $\mathbf{6 a}$ after recrystallization from $\mathrm{MeOH}$ in $60 \%$ yield (Scheme 2).

The corresponding nonfluorinated sulfonimide $\mathrm{K}^{+}$-salt $\mathbf{6 b}$ was obtained by deprotonation of methanesulfonamide (5b) with $\mathrm{NaH}$ followed by treatment with sulfonyl chloride $\mathbf{4}$ according to a method by Dick and Townsend [41]. Analogous deprotonation with $\mathrm{KOH}$ yielded $\mathbf{6 b}$ in $71 \%$.

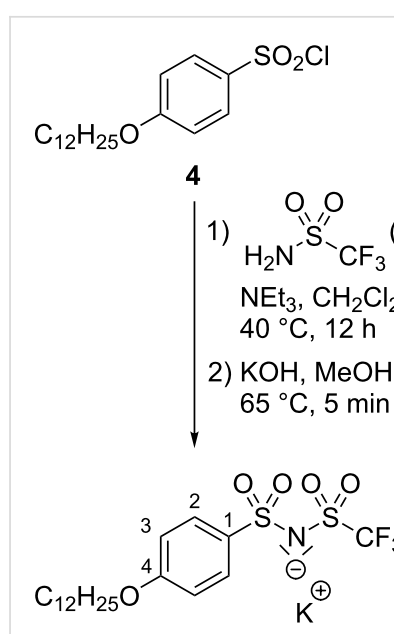<smiles>CS(N)(=O)=O</smiles>

5b (5a)

1) $\mathrm{NaH}, \mathrm{DMF}$

$\mathrm{rt}, 1 \mathrm{~h}$

2) 4 , THF

$0^{\circ} \mathrm{C} \rightarrow \mathrm{rt}, 3 \mathrm{~d}$

3) $\mathrm{HCl}_{\mathrm{aq}}$.

4) $\mathrm{KOH}, \mathrm{MeOH}$

$\mathrm{rt}, 5 \mathrm{~min}$ 6a, $60 \%$

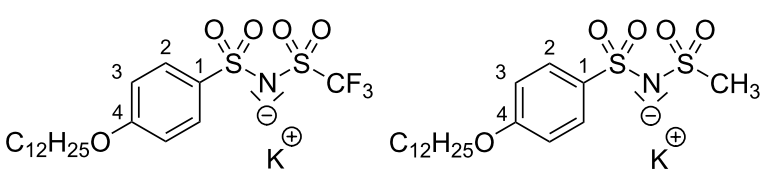

6b, $71 \%$
Scheme 2: Synthesis of the potassium sulfonimides $\mathbf{6 a}$ and $\mathbf{6 b}$.

The $\mathrm{K}^{+}$-salts were prepared due to their more convenient isolation as compared to the corresponding protonated compounds. However, the $\mathrm{K}^{+}$-sulfonimides $\mathbf{6 a}$, $\mathbf{b}$ were not used for a direct methyl transfer towards the synthesis of the desired guanidinium-sulfonimide ion pairs in a similar way that the arylsulfonic acid methylesters were previously used as methyl transfer reagents [38], because we wanted to avoid the activation with dimethyl sulfate reported by DesMarteau [21]. Therefore we planned an indirect formation of the ion pairs by anion exchange via salt metathesis. In order to be successful, two requirements have to be met. First, the solubility of the sulfonimide salts 6a,b in the solvent must be sufficient. Second, one of the products must be insoluble in order to shift the equilibrium towards complete conversion. In contrast to the sodium 4-alkoxyphenylsulfonates both potassium salts $\mathbf{6 a}, \mathbf{b}$ are soluble in boiling $\mathrm{MeCN}$, so that both conditions for a successful salt metathesis are fulfilled.

The known guanidinium chloride $7 \cdot \mathrm{Cl}$ [42] was treated with $\mathrm{MeI}$ in the presence of $\mathrm{K}_{2} \mathrm{CO}_{3}$ to afford the $\mathrm{N}$-methylated guanidinium iodide 8·I (Scheme 3) [38,39].

However, this intermediate did not allow a salt metathesis, because the resulting $\mathrm{KI}$ is highly soluble in $\mathrm{MeCN}$ (and other organic solvents). Therefore, the intermediate was treated with $\mathrm{AgNO}_{3}$ in $\mathrm{MeOH}$. The resulting $\mathrm{N}$-methylated guanidinium nitrate was then reacted with $\mathbf{6 a}$ or $\mathbf{6 b}$ in $\mathrm{MeCN}$ to the desired ion pairs $\mathbf{2 a}$ and $\mathbf{2 b}$ in $79 \%$ and $75 \%$ yield, respectively, while the precipitating $\mathrm{KNO}_{3}$ shifted the salt metathesis to completion (Scheme 3).

The good solubility of the $\mathrm{K}^{+}$-sulfonimide salts $\mathbf{6 a}, \mathbf{b}$ in $\mathrm{MeCN}$ was further used for a salt metathesis towards the $\mathrm{N}$-protonated 
2a, $79 \% ; \mathbf{2 b}, 75 \%$

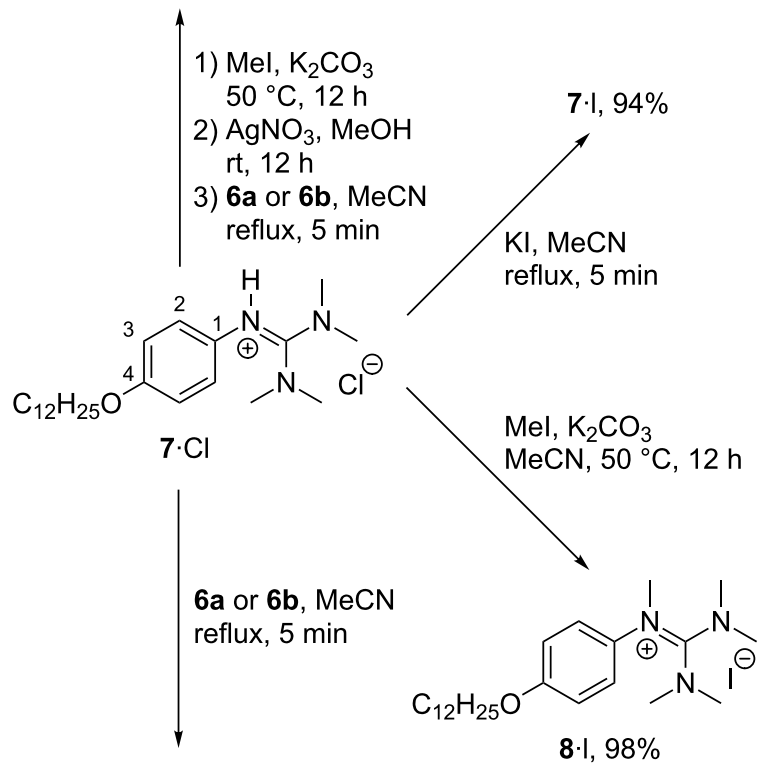

3a, $77 \% ; \mathbf{3 b}, 96 \%$

Scheme 3: Synthesis of guanidinium sulfonimides $\mathbf{2} \mathbf{a}, \mathbf{b}, \mathbf{3} \mathbf{a}, \mathbf{b}$ and iodides $7 \cdot \mathbf{I}, \mathbf{8} \cdot \mathbf{I}$.

guanidinium-sulfonimide ion pairs $\mathbf{3 a}, \mathbf{b}$ by heating $7 \cdot \mathrm{Cl}$ with $\mathbf{6 a}$ or $\mathbf{6 b}$ under reflux. The resulting ion pairs $\mathbf{3 a}$ and $\mathbf{3 b}$ were isolated in $77 \%$ and $96 \%$ yield, respectively. In comparison the guanidinium iodide $7 \cdot \mathrm{I}$ was obtained in $94 \%$ yield by heating 7. $\mathrm{Cl}$ with $\mathrm{KI}$ in $\mathrm{MeCN}$ under reflux (Scheme 3 ). The mesomorphic properties of ion pairs $\mathbf{2 , 3}$ and guanidinium halides $7 \cdot \mathrm{I}$, $7 \cdot \mathrm{Cl}, \mathbf{8} \cdot \mathrm{I}$ were studied by differential scanning calorimetry (DSC) and polarizing optical microscopy (POM). The results of the DSC experiments are summarized in Table 1.
N-Methylated guanidinium sulfonimides $\mathbf{2 a}, \mathbf{b}$ revealed only isotropic melting at $61{ }^{\circ} \mathrm{C}$ and $93{ }^{\circ} \mathrm{C}$, respectively (Table 1 , entries 1 and 2), while $\mathrm{N}$-methylated guanidinium iodide $8 \cdot \mathrm{I}$ melted at $117{ }^{\circ} \mathrm{C}$ (Table 1 , entry 3 ). In comparison, the $\mathrm{N}$-methylated guanidinium sulfonate $\mathbf{1}$ displayed a melting transition at $99{ }^{\circ} \mathrm{C}$ in the $\mathrm{SmA}$ phase and isotropic clearing at $148{ }^{\circ} \mathrm{C}$ (Table 1 , entry 8 ). Thus, while the presence of the sulfonimide anions in $\mathbf{2 a}, \mathbf{b}$ indeed led to a decrease of the melting point as compared to the corresponding iodide $\mathbf{8} \cdot \mathrm{I}$, the formation of a smectic mesophase was completely suppressed. For protonated guanidinium sulfonimides $\mathbf{3 a}, \mathbf{b}$ again a significant decrease of the melting temperature was found $\left(75^{\circ} \mathrm{C}\right.$ and $71^{\circ} \mathrm{C}$, respectively, Table 1 , entries 4 and 5) as compared to the protonated guanidinium iodide $7 \cdot \mathrm{I}$, which melted at $130{ }^{\circ} \mathrm{C}$ into the isotropic phase (Table 1, entry 6). The protonated chloride $7 \cdot \mathrm{Cl}$ showed a melting transition at $121^{\circ} \mathrm{C}$ into the SmA phase, and a clearing transition at $128{ }^{\circ} \mathrm{C}$ (Table 1, entry 7) [42]. However, while the trifluoromethyl-substituted sulfonimide $\mathbf{3 a}$ displayed only three crystal-to-crystal transitions at 8, 19 and $37^{\circ} \mathrm{C}$, respectively, besides isotropization at $75^{\circ} \mathrm{C}$, the corresponding methyl-substituted sulfonimide $\mathbf{3 b}$ showed two crystalto-crystal transitions at $5{ }^{\circ} \mathrm{C}$ and $27{ }^{\circ} \mathrm{C}$, respectively, a melting transition into the smectic A phase at $71{ }^{\circ} \mathrm{C}$ and a clearing point at $87^{\circ} \mathrm{C}$. Thus, sulfonimide-containing ion pair $\mathbf{3 b}$ indeed led to a mesophase albeit with only $16 \mathrm{~K}$ phase width as compared to $49 \mathrm{~K}$ phase width of the guanidinium sulfonate 1 . The DSC traces of $\mathbf{3 b}$ are shown in Figure 1.

POM observations of $\mathbf{3 b}$ upon cooling from the isotropic liquid revealed fan-shaped textures and homeotropic alignment (Figure 2) typical for SmA phases.

The mesophase of compound $\mathbf{3 b}$ was investigated by X-ray scattering (WAXS and SAXS) at different temperatures. The

\begin{tabular}{|c|c|c|}
\hline Entry & Compound & $\begin{array}{l}\text { Phase transitions (onset }\left({ }^{\circ} \mathrm{C}\right) \text { ) and transition enthalpies (given in parentheses) }\left(\mathrm{kJ} \mathrm{mol}^{-1}\right) \text { upon } \\
\text { second heating }\end{array}$ \\
\hline 1 & $2 a$ & $\operatorname{Cr} 61(31.8) I^{b}$ \\
\hline 2 & $2 b$ & Cr $93(59.1) I$ \\
\hline 3 & $8 \cdot 1$ & $\mathrm{Cr}_{1} 49(8.4) \mathrm{Cr}_{2} 117(25.8) \mathrm{I}^{\mathrm{C}}$ \\
\hline 4 & $3 \mathbf{a}$ & $\mathrm{Cr}_{1} 8(18.6) \mathrm{Cr}_{2} 19(0.8) \mathrm{Cr}_{3} 37(-44.9) \mathrm{Cr}_{4} 75$ (48.6)। \\
\hline 5 & $3 b$ & $\mathrm{Cr}_{1} 5(8.1) \mathrm{Cr}_{2} 27(-54.4) \mathrm{Cr}_{3} 71(73.1) \mathrm{SmA} 87(1.4) \mathrm{I}$ \\
\hline 6 & $7 \cdot 1$ & $\mathrm{Cr}_{1} 55(-44.3) \mathrm{Cr}_{2} 130(37.2) \mathrm{I}$ \\
\hline 7 & $7 \cdot \mathrm{Cl}$ & Cr 121 (29.9) SmA $128(0.7) \mathrm{I}^{\mathrm{b}, \mathrm{d}}$ \\
\hline 8 & 1 & $\mathrm{Cr}_{1} 51(-5.1) \mathrm{Cr}_{2} 99(61.6) \mathrm{SmA} 148(1.9) I^{\mathrm{C}}$ \\
\hline
\end{tabular}

aThe following phases were observed: Cr Crystalline, SmA Smectic A, I Isotropic. Heating rate $10 \mathrm{~K} \mathrm{~min}^{-1}$. bUpon 1 st heating. ${ }^{\mathrm{c} D a t a}$ for compounds $8 \cdot I$ and 1 were taken from [38]. ${ }^{\mathrm{d}}$ Data for compound $7 \cdot \mathrm{Cl}$ was taken from [42]; heating rate $5 \mathrm{~K} \mathrm{~min}^{-1}$. 


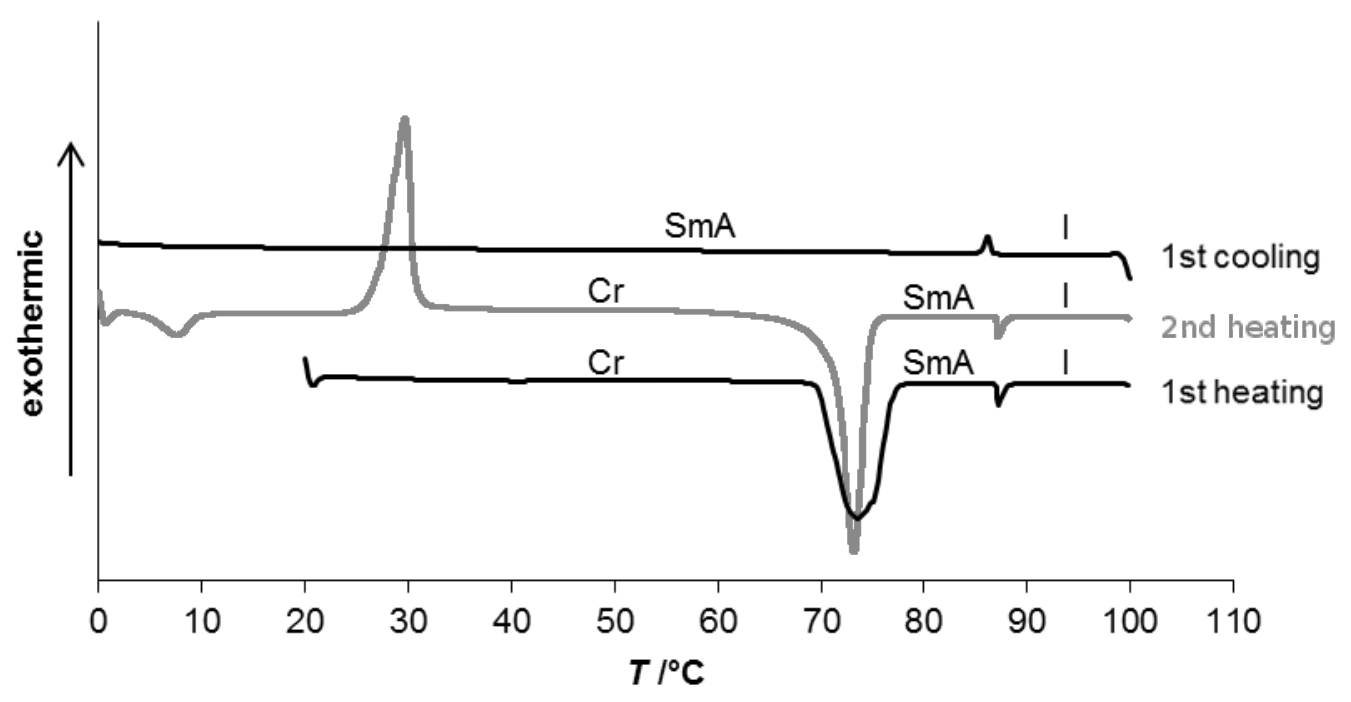

Figure 1: DSC traces of compound $3 \mathbf{b}$ (heating/cooling rate $10 \mathrm{~K} \mathrm{~min}^{-1}$ ).
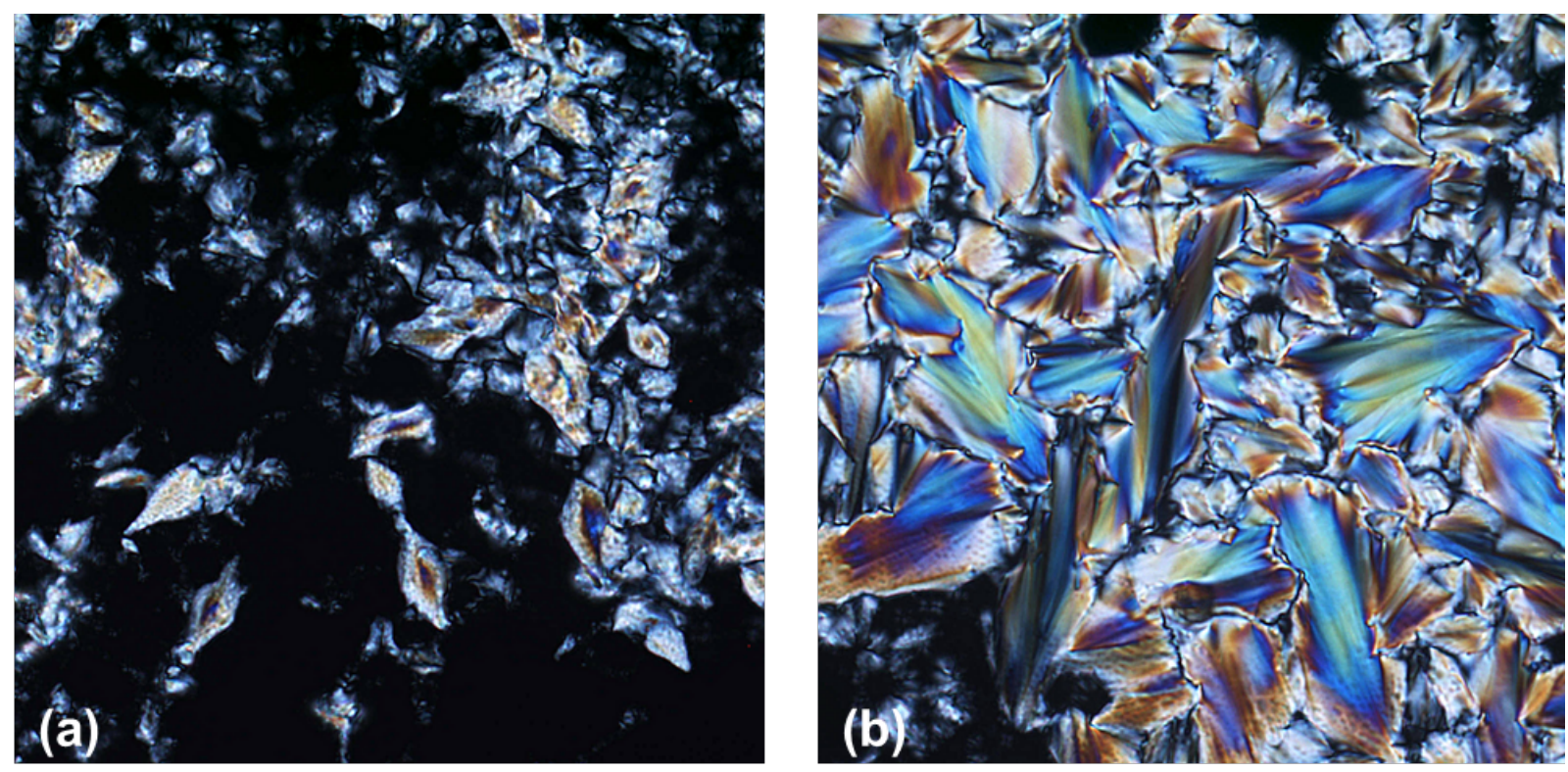

Figure 2: Compound $\mathbf{3 b}$ under crossed polarizers upon cooling from the isotropic melt (200-fold magnification). (a) Homeotropic texture at $80{ }^{\circ} \mathrm{C}$ (cooling rate $\left.10 \mathrm{~K} \mathrm{~min}^{-1}\right)$; (b) fan-shaped texture at $88^{\circ} \mathrm{C}$ (cooling rate $1 \mathrm{~K} \mathrm{~min}^{-1}$ ).

XRD experiments revealed diffraction patterns with a single diffraction peak and a diffuse halo at $4.7 \AA$ resulting from the alkyl chains (Figure 3 ). These patterns are typical for smectic mesophases and further confirm the assignment of a SmA phase based on POM observations.

The exact layer spacing at each temperature was determined by fitting the first-order peak with a Gaussian distribution (Figure 3 and Supporting Information File 1, Table S1) and decreases with rising temperatures. To allow a comparison with the layer spacings of compounds $\mathbf{1}$ and $\mathbf{7} \cdot \mathrm{Cl}$, the layer spacing of $\mathbf{3 b}$ was determined at a reduced temperature $\left(T_{\text {red }}=\right.$ $0.95 \cdot T_{\text {iso }}$ ) by linear extrapolation of the obtained data (Table 2 ). The obtained value of $d_{\text {red }}=32.6 \AA$ (Table 2) is in good agreement with the values determined for salts $7 \cdot \mathrm{Cl}(34.0 \AA$ [42]) and 1 (32.2 $\AA$ [38]) bearing the same $(7 \cdot \mathrm{Cl})$ or nearly the same (N-Me instead of N-H) cation 1. As the layer spacing is much larger $(32.6 \AA)$ compared to the calculated length of the cation 
(a)

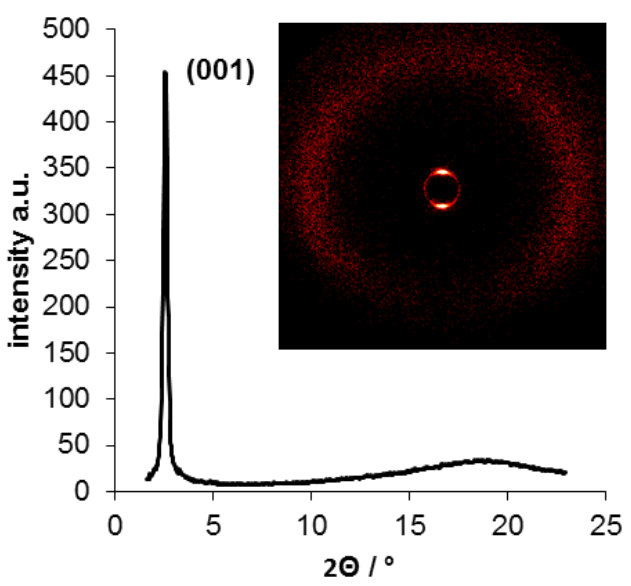

(b)

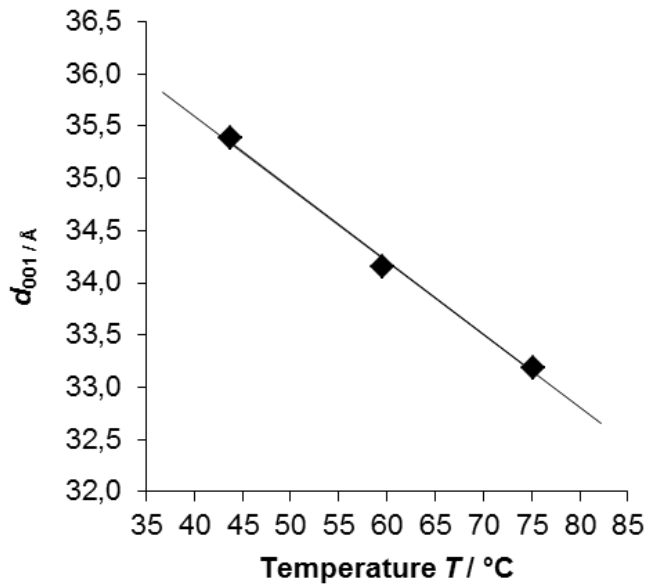

Figure 3: (a) WAXS diffraction pattern of $\mathbf{3 b}$ at $59.5^{\circ} \mathrm{C}$ (vertical magnetic field director); (b) temperature-dependent layer spacing of compound $\mathbf{3 b}$

and anion (23-24 $\AA$, Table 2), we propose the formation of mixed double layers with the charged heads of cation and anion pointing to each other. This packing behavior is in good agreement with those reported for guanidinium sulfonate $\mathbf{1}$ [38].

\begin{tabular}{|c|c|c|c|c|}
\hline Compound & $T_{\text {red }} /\left[{ }^{\circ} \mathrm{C}\right]$ & $d_{\text {red }} /[\AA]$ & $\begin{array}{l}L_{\text {calc }} \\
\text { (cation)/[A] }\end{array}$ & $\begin{array}{l}L_{\text {calc }} \\
\text { (anion)/[A] }]\end{array}$ \\
\hline $3 b$ & 83 & 32.6 & $23.8^{a}$ & $22.7^{a}$ \\
\hline $7 \cdot \mathrm{Cl}^{\mathrm{b}}$ & 122 & 34.0 & 23.9 & $1.81^{\mathrm{C}}$ \\
\hline $1^{d}$ & 141 & 32.2 & 23.0 & 21.0 \\
\hline
\end{tabular}

aCalculated using Chem3D Ultra, Cambridgesoft, 2011. bValues were taken from [42]. CValue was taken from [43]. dValues were taken from [38].

\section{Conclusion}

We have developed a route towards guanidinium-sulfonimide ion pairs in which both anion and cation contain mesogenic units. The replacement of a spherical halide counterion by a calamitic sulfonimide anion indeed led to a decrease of the melting points, the effect being larger for trifluorosulfonimides $\mathbf{2 a}$ and $\mathbf{3 a}$ as compared to methylsulfonimides $\mathbf{2} \mathbf{b}$ and $\mathbf{3 b}$. It should be noted that Strassner has recently introduced a different concept to tune melting points in ionic liquids by electronic effects of the aryl substituent $[44,45]$. However, the mesogenic sulfonimide resulted in the formation of a SmA mesophase only in the case of $\mathbf{3 b}$, while ion pairs $\mathbf{2} \mathbf{a}, \mathbf{b}$ and $\mathbf{3 a}$ did not show any liquid-crystalline properties. Thus, the presence of mesogenic counterions could not overcome the known tendency of sulfonimides to inhibit mesomorphism.

\section{Experimental}

General Information. All reactions were carried out under a nitrogen atmosphere with Schlenk-type glassware and the solvents were dried and distilled under nitrogen prior to use. Characterization of the compounds was carried out by using the following instruments. Elemental analyses: Carlo Erba Strumentazione Elemental Analyzer, Modell 1106. NMR: Bruker Avance $500\left({ }^{1} \mathrm{H}, 500 \mathrm{MHz} ;{ }^{13} \mathrm{C}, 125 \mathrm{MHz}\right)$. IR: Bruker Vector 22 FTIR spectrometer with MKII golden gate single reflection diamond ATR system. ${ }^{1} \mathrm{H}$ and ${ }^{13} \mathrm{C}$ NMR spectra were recorded at room temperature and referenced to TMS $\left(\mathrm{Me}_{4} \mathrm{Si}\right.$ $\left.\delta_{\mathrm{H}}=0.0 \mathrm{ppm}, \delta_{\mathrm{C}}=0.0 \mathrm{ppm}\right)$ as an internal standard. The assignment of the resonances was supported by chemical shift calculations and 2D experiments (COSY and HMBC). MS (EI): Varian MAT 711 spectrometer. Polarizing optical microscopy: Olympus BX50 polarizing microscope combined with a Linkam TP93 central controller. MS (ESI): Bruker Daltonics microTOF-Q spectrometer. Differential scanning calorimetry (DSC): Mettler-Toledo DSC 822e (heating/cooling rates were $10 \mathrm{~K} \mathrm{~min}^{-1}$ ). X-ray diffraction (WAXS, SAXS regions): Bruker AXS Nanostar $\mathrm{C}$ diffractometer employing Ni-filtered $\mathrm{Cu} \mathrm{K} \alpha$ radiation $(\lambda=1.5418 \AA$ ). Melting points: Büchi SMP-20. Water content: Metrohm 831 Coulometric Karl Fischer Titrator, (generator electrode with a diaphragm), HYDRANALCoulomat AG and HYDRANAL-Coulomat CG solutions were used.

Compounds $\mathbf{4}$ and 5a,b are commercially available. Full characterization of compounds $\mathbf{1}$ and $\mathbf{8} \cdot \mathrm{I}$ is given in [38], and for compound $7 \cdot \mathrm{Cl}$ in [42]. For compounds $\mathbf{2 b}, \mathbf{3 a}$ and 7.I the following water content was determined by Karl Fischer titration: $0.38 \%$, $0.36 \%$ and $0.13 \%$, respectively (see Supporting Information File 1, Table S2). 
4-(Dodecyloxy)- $N$-((trifluoromethyl)sulfonyl)benzenesulfonamide, potassium salt (6a): A mixture of trifluoromethanesulfonamide (5a) (207 mg, $1.38 \mathrm{mmol})$ and 4-(dodecyloxy)benzenesulfonylchloride (4) (500 mg, $1.39 \mathrm{mmol})$ was dissolved in abs dichloromethane $(20 \mathrm{~mL})$. Abs triethylamine ( $1 \mathrm{~mL}, 701 \mathrm{mg}, 6.93 \mathrm{mmol}$ ) was added and the resulting mixture was heated under reflux for $12 \mathrm{~h}$. After cooling to room temperature the solvent was removed in vacuo, the residue was taken up in ethyl acetate $(100 \mathrm{~mL})$, and the hot suspension was filtered. The filtrate was evaporated to dryness and the residue was purified by flash chromatography with ethyl acetate as eluent. The resulting solid was taken up in methanol $(20 \mathrm{~mL})$, potassium hydroxide $(78 \mathrm{mg}, 1.39 \mathrm{mmol}$ ) was added, and the mixture was heated under reflux for $5 \mathrm{~min}$. After cooling to $0{ }^{\circ} \mathrm{C}$ product 6 a precipitated as a colorless solid. Yield: $425 \mathrm{mg}$ (60\%); colorless solid; $\mathrm{mp}>300{ }^{\circ} \mathrm{C}$; ${ }^{1} \mathrm{H}$ NMR $(500 \mathrm{MHz}$, DMSO- $\left.d_{6}\right) \delta 0.85\left(\mathrm{t}, J=7.2 \mathrm{~Hz}, 3 \mathrm{H}, \mathrm{CH}_{3}\right), 1.17-1.35(\mathrm{~m}, 16 \mathrm{H}$, $\left.\mathrm{CH}_{2}\right), 1.36-1.43\left(\mathrm{~m}, 2 \mathrm{H}, \mathrm{CH}_{2}\right), 1.67-1.74\left(\mathrm{~m}, 2 \mathrm{H}, \mathrm{CH}_{2}\right), 4.01$ $\left(\mathrm{t}, J=6.5 \mathrm{~Hz}, 2 \mathrm{H}, \mathrm{OCH}_{2}\right), 6.94-7.00(\mathrm{~m}, 2 \mathrm{H}, 3-\mathrm{H}), 7.62-7.68$ $(\mathrm{m}, 2 \mathrm{H}, 2-\mathrm{H}) \mathrm{ppm} ;{ }^{13} \mathrm{C}$ NMR $\left(125 \mathrm{MHz}, \mathrm{DMSO}-d_{6}\right) \delta 13.9$ $\left(\mathrm{CH}_{3}\right), 22.1,25.4,28.5,28.68,28.71,28.95,28.98,29.031 .3$ $\left(\mathrm{CH}_{2}\right), 67.7\left(\mathrm{OCH}_{2}\right), 113.8(\mathrm{C}-3), 128.1(\mathrm{C}-2), 137.1(\mathrm{C}-1)$, 160.5 (C-4) ppm; FTIR (ATR) $\tilde{v}: 2917$ (m), 2848 (m), 1597 (m), $1584(\mathrm{~m}), 1497$ (m), 1467 (m), 1387 (w), 1329 (s), 1284 (m), $1254(\mathrm{~m}), 1232$ (m), 1206 (m), 1160 (vs), 1114 (m), 1093 (s), $1058(\mathrm{~s}), 956(\mathrm{w}), 867(\mathrm{w}), 833(\mathrm{~m}), 801(\mathrm{w}), 780(\mathrm{~s}), 746$ (s), $718(\mathrm{w}), 683(\mathrm{~m}) \mathrm{cm}^{-1}$; ESIMS $(\mathrm{m} / \mathrm{z}): 472[\mathrm{M}]^{-}, 303\left[\mathrm{M}^{-}-\right.$ $\mathrm{C}_{12} \mathrm{H}_{25}$ ]; HRMS-ESI $(\mathrm{m} / \mathrm{z})$ : [M] $]^{-}$calcd for $\mathrm{C}_{19} \mathrm{H}_{29} \mathrm{~F}_{3} \mathrm{NO}_{5} \mathrm{~S}_{2}{ }^{-}$, 472.1445; found, 472.1427.

4-(Dodecyloxy)- $N$-((methylsulfonyl)benzenesulfonamide, potassium salt (6b): Methanesulfonamide (5b) $(277 \mathrm{mg}$, $2.91 \mathrm{mmol})$ was given to a suspension of sodium hydride (333 $\mathrm{mg}, 8.31 \mathrm{mmol})$ in abs DMF $(10 \mathrm{~mL})$ and the mixture was stirred for $1 \mathrm{~h}$. After cooling to $0{ }^{\circ} \mathrm{C}$ a solution of 4-(dodecyloxy)benzenesulfonylchloride $(4,1.00 \mathrm{~g}, 2.77 \mathrm{mmol})$ in abs THF $(5 \mathrm{~mL})$ was added dropwise and the reaction mixture was warmed to room temperature. After being stirred for 3 days, the mixture was brought to $\mathrm{pH} 1$ by the addition of concd hydrochloric acid. The solvents were removed in vacuo and the residue was taken up in dichloromethane $(50 \mathrm{~mL})$. The resulting solution was dried with magnesium sulfate and filtered, and the filtrate was evaporated to dryness. The residue was taken up in methanol $(30 \mathrm{~mL})$ and treated with potassium hydroxide (156 mg, $2.77 \mathrm{mmol}$ ) for $5 \mathrm{~min}$. After cooling the mixture to $0{ }^{\circ} \mathrm{C}$ the product $\mathbf{6 b}$ precipitated as a colorless solid. Yield: $901 \mathrm{mg}$ (71\%); colorless solid; $\mathrm{mp}>300{ }^{\circ} \mathrm{C}$; ${ }^{1} \mathrm{H}$ NMR $\left(500 \mathrm{MHz}, \mathrm{DMSO}-d_{6}\right) \delta 0.86\left(\mathrm{t}, J=6.8 \mathrm{~Hz}, 3 \mathrm{H}, \mathrm{CH}_{3}\right)$, $1.18-1.35\left(\mathrm{~m}, 16 \mathrm{H}, \mathrm{CH}_{2}\right), 1.36-1.43\left(\mathrm{~m}, 2 \mathrm{H}, \mathrm{CH}_{2}\right), 1.66-1.74$ $\left(\mathrm{m}, 2 \mathrm{H}, \mathrm{CH}_{2}\right), 2.72\left(\mathrm{~s}, 3 \mathrm{H}, \mathrm{SO}_{2} \mathrm{CH}_{3}\right), 3.98(\mathrm{t}, J=6.5 \mathrm{~Hz}, 2 \mathrm{H}$, $\left.\mathrm{OCH}_{2}\right), 6.86-6.92(\mathrm{~m}, 2 \mathrm{H}, 3-\mathrm{H}), 7.59-7.64$ (m, 2H, 2-H) ppm;
${ }^{13} \mathrm{C}$ NMR (125 MHz, DMSO- $\left.d_{6}\right) \delta 13.9\left(\mathrm{CH}_{3}\right), 22.0,25.4,28.5$, 28.6, 28.7, 28.90, 28.91, 28.94, $31.2\left(\mathrm{CH}_{2}\right), 42.6\left(\mathrm{SO}_{2} \mathrm{CH}_{3}\right)$, $67.5\left(\mathrm{OCH}_{2}\right), 113.2(\mathrm{C}-3), 128.0(\mathrm{C}-2), 138.8(\mathrm{C}-1), 159.6$ (C-4) ppm; FTIR (ATR) $\tilde{v}$ : 3077 (w), 2914 (s), 2849 (m), 1595 (m), 1498 (m), 1473 (m), 1394 (m), 1274 (s), 1248 (s), 1152 (s), 1126 (s), 1089 (vs), 972 (m), 831 (s), 808 (s), 721 (s), 679 (m), $590(\mathrm{~s}), 525(\mathrm{vs}) \mathrm{cm}^{-1}$; ESIMS $(\mathrm{m} / \mathrm{z}): 418[\mathrm{M}]^{-}, 340\left[\mathrm{M}^{-}-\right.$ $\left.\mathrm{CH}_{3} \mathrm{O}_{2} \mathrm{~S}+\mathrm{H}\right], 249\left[\mathrm{M}^{-}-\mathrm{C}_{12} \mathrm{H}_{25}\right]$; HRMS-ESI $(\mathrm{m} / \mathrm{z}):[\mathrm{M}]^{-}$ calcd for $\mathrm{C}_{19} \mathrm{H}_{32} \mathrm{NO}_{5} \mathrm{~S}_{2}{ }^{-}$, 418.1727; found, 418.1728.

\section{General procedure for the preparation of pentamethylguanidinium ion pairs $(\mathbf{2} \mathbf{a}, \mathbf{b})$}

Potassium carbonate $(144 \mathrm{mg}, 971 \mu \mathrm{mol})$ and methyl iodide (207 mg, $1.46 \mathrm{mmol}$ ) were added to a solution of guanidinium chloride $(7 \cdot \mathrm{Cl}, 200 \mathrm{mg}, 485 \mu \mathrm{mol})$ in acetonitrile $(20 \mathrm{~mL})$. The resulting mixture was heated to $50{ }^{\circ} \mathrm{C}$ for $12 \mathrm{~h}$ and then cooled to room temperature, and the solvent was removed in vacuo. The residue was taken up in dichloromethane $(20 \mathrm{~mL})$ and filtered, and the filtrate was concentrated to dryness. A solution of the residue in methanol $(20 \mathrm{~mL})$ was treated with silver nitrate $(165 \mathrm{mg}, 971 \mu \mathrm{mol})$ and stirred for $12 \mathrm{~h}$ at room temperature under the exclusion of light. The solvent was removed under reduced pressure, the residue was taken up in dichloromethane $(20 \mathrm{~mL})$, and the slurry was filtered by using a Rotilabo-syringe filter. After concentration of the filtrate to dryness, the residue was taken up in acetonitrile $(10 \mathrm{~mL})$, and sulfonimide salt $\mathbf{6 a}$ or $\mathbf{6 b}(509 \mu \mathrm{mol})$ was added. The mixture was heated under reflux for $5 \mathrm{~min}$, the solvent was removed in vacuo, and the residue was taken up in dichloromethane $(20 \mathrm{~mL})$. After filtration with a Rotilabo-syringe filter the solvent was removed in vacuo, and the crude product was recrystallized from ethyl acetate.

$N$-(4-(Dodecyloxy)phenyl)- $N, N^{\prime}, N^{\prime}, N^{\prime}, N^{\prime}$ '-pentamethylguanidinium ((4-(dodecyloxy)phenyl)sulfonyl)((trifluoromethyl)sulfonyl)amide (2a): Yield: $330 \mathrm{mg}$ (79\%); colorless solid; ${ }^{1} \mathrm{H} \mathrm{NMR}\left(500 \mathrm{MHz}, \mathrm{CDCl}_{3}\right) \delta 0.88(\mathrm{t}, J=6.8 \mathrm{~Hz}$, $\left.6 \mathrm{H}, \mathrm{CH}_{3}\right), 1.20-1.38\left(\mathrm{~m}, 32 \mathrm{H}, \mathrm{CH}_{2}\right), 1.40-1.48\left(\mathrm{~m}, 4 \mathrm{H}, \mathrm{CH}_{2}\right)$, 1.73-1.82 (m, 4H, $\mathrm{OCH}_{2} \mathrm{CH}_{2}$ ), 2.82, 3.07 (br s, $12 \mathrm{H}, \mathrm{N}\left[\mathrm{CH}_{3}\right]_{2}$ ), $3.39\left(\mathrm{~s}, 3 \mathrm{H}, \mathrm{NCH}_{3}\right), 3.94\left(\mathrm{t}, J=6.5 \mathrm{~Hz}, 2 \mathrm{H}, \mathrm{OCH}_{2}\right), 3.97$ (t, $J=$ $\left.6.5 \mathrm{~Hz}, 2 \mathrm{H}, \mathrm{OCH}_{2}\right), 6.87-6.95(\mathrm{~m}, 2 \mathrm{H}, 3-\mathrm{H}, 3$ 3"-H), 6.97-7.02 $(\mathrm{m}, 2 \mathrm{H}, 2-\mathrm{H}), 7.88-7.92(\mathrm{~m}, 2 \mathrm{H}, 2$ "- $\mathrm{H}) \mathrm{ppm} ;{ }^{13} \mathrm{C} \mathrm{NMR}$ $\left(125 \mathrm{MHz}, \mathrm{CDCl}_{3}\right) \delta 14.1\left(\mathrm{CH}_{3}\right), 22.7,25.98,26.01,29.11$, 29.18, 29.36, 29.39, 29.40, 29.57, 29.61, 29.64, 29.67, 31.9 $\left(\mathrm{CH}_{2}\right), 40.2\left(\mathrm{NCH}_{3}\right), 40.2,41.1$ (br s, $\left.\mathrm{N}\left(\mathrm{CH}_{3}\right)_{2}\right), 68.3,68.5$ $\left(\mathrm{OCH}_{2}\right), 114.1$ (C-3”), 115.9 (C-3), 123.4 (C-2), 129.3 (C-2”), 134.65, 134.72 (C-1, C-1”), 157.7 (C-4), 162.0 (C-4”), 162.2 (C-1') ppm; ${ }^{19} \mathrm{~F}$ NMR (235 MHz, $\left.\mathrm{CDCl}_{3}\right) \delta-77.0\left(\mathrm{CF}_{3}\right) \mathrm{ppm}$; FTIR (ATR) $\tilde{v}: 2918(\mathrm{~s}), 2850(\mathrm{~m}), 1611(\mathrm{~m}), 1597(\mathrm{~m}), 1555$ (m), $1511(\mathrm{~m}), 1473(\mathrm{~m}), 1410(\mathrm{~m}), 1350(\mathrm{~m}), 1323$ (s), 1288 (m), 1246 (s), 1221 (m), 1173 (vs), 1132 (s), 1093 (s), 1056 (s), 
999 (s), $897(\mathrm{~m}), 837(\mathrm{~m}), 797(\mathrm{~m}), 720(\mathrm{w}), 687(\mathrm{~m}) \mathrm{cm}^{-1}$; $\operatorname{ESIMS~}(\mathrm{m} / \mathrm{z}): 390[\mathrm{M}]^{+}, 222\left[\mathrm{M}^{+}-\mathrm{C}_{12} \mathrm{H}_{25}+\mathrm{H}\right] ; \operatorname{ESIMS}(\mathrm{m} / \mathrm{z})$ : $472[\mathrm{M}]^{-}, 303\left[\mathrm{M}^{-}-\mathrm{C}_{12} \mathrm{H}_{25}\right]$; HRMS-ESI $(\mathrm{m} / \mathrm{z})$ : $[\mathrm{M}]^{+}$calcd for $\mathrm{C}_{24} \mathrm{H}_{44} \mathrm{~N}_{3} \mathrm{O}^{+}$, 390.3479; found, 390.3456; HRMS-ESI $(\mathrm{m} / \mathrm{z})$ : $[\mathrm{M}]^{-}$calcd for $\mathrm{C}_{19} \mathrm{H}_{29} \mathrm{~F}_{3} \mathrm{NO}_{5} \mathrm{~S}_{2}{ }^{-}, 472.1434$; found, 472.1438; DSC: $\mathrm{Cr} 61{ }^{\circ} \mathrm{C}\left[31.8 \mathrm{~kJ} \mathrm{~mol}^{-1}\right] \mathrm{I}$.

$N$-(4-(Dodecyloxy)phenyl)- $N, N^{\prime}, N^{\prime}, N^{\prime}, N^{\prime}$-pentamethylguanidinium ((4-(dodecyloxy)phenyl)sulfonyl)(methylsulfonyl)amide (2b): Yield: $94 \mathrm{mg}(75 \%)$; colorless solid; ${ }^{1} \mathrm{H}$ NMR $\left(500 \mathrm{MHz}, \mathrm{CDCl}_{3}\right) \delta 0.88\left(\mathrm{t}, J=6.9 \mathrm{~Hz}, 6 \mathrm{H}, \mathrm{CH}_{3}\right)$, $1.20-1.39\left(\mathrm{~m}, 32 \mathrm{H}, \mathrm{CH}_{2}\right), 1.39-1.48\left(\mathrm{~m}, 4 \mathrm{H}, \mathrm{CH}_{2}\right), 1.73-1.81$ $\left(\mathrm{m}, 4 \mathrm{H}, \mathrm{OCH}_{2} \mathrm{CH}_{2}\right), 2.82,3.09$ (br s, $\left.12 \mathrm{H}, \mathrm{N}\left[\mathrm{CH}_{3}\right]_{2}\right), 3.41(\mathrm{~s}$, $\left.3 \mathrm{H}, \mathrm{NCH}_{3}\right), 2.90\left(\mathrm{~s}, 3 \mathrm{H}, \mathrm{SO}_{2} \mathrm{CH}_{3}\right), 3.90-3.97\left(\mathrm{~m}, 4 \mathrm{H}, \mathrm{OCH}_{2}\right)$ 6.82-6.87 (m, 2H, 3"-H), 6.89-6.94 (m, 2H, 3-H), 7.00-7.05 (m, 2H, 2-H), 7.87-7.92 (m, 2H, 2"-H) ppm; ${ }^{13} \mathrm{C} \mathrm{NMR}$ $\left(125 \mathrm{MHz}, \mathrm{CDCl}_{3}\right) \delta 14.1\left(\mathrm{CH}_{3}\right), 22.7,26.0,29.19,29.20$, 29.35, 29.40, 29.58, 29.64, 29.67, $31.9\left(\mathrm{CH}_{2}\right), 40.3\left(\mathrm{NCH}_{3}\right)$, 40.3, 41.2 (br s, $\left.\mathrm{N}\left(\mathrm{CH}_{3}\right)_{2}\right), 42.2\left(\mathrm{SO}_{2} \mathrm{CH}_{3}\right), 68.1,68.4\left(\mathrm{OCH}_{2}\right)$, 113.6 (C-3"), 115.8 (C-3), 123.4 (C-2), 128.7 (C-2”), 135.0 (C-1), 137.8 (C-1"), 157.4 (C-4), 160.7 (C-4”), 162.2 (C-1') ppm; FTIR (ATR) $\tilde{v}: 2919(\mathrm{~s}), 2850(\mathrm{~m}), 1612(\mathrm{~m}), 1552(\mathrm{~m})$, $1510(\mathrm{~m}), 1469(\mathrm{~m}), 1403(\mathrm{~m}), 1296(\mathrm{w}), 1268(\mathrm{~s}), 1241(\mathrm{~s})$, $1177(\mathrm{~m}), 1143(\mathrm{~m}), 1122(\mathrm{~s}), 1086(\mathrm{~s}), 1051(\mathrm{~s}), 1001(\mathrm{w}), 948$ (w), $897(\mathrm{w}), 837(\mathrm{~m}), 801(\mathrm{~m}), 721(\mathrm{~s}), 653$ (s), $587(\mathrm{vs}) \mathrm{cm}^{-1}$; $\operatorname{ESIMS~}(\mathrm{m} / \mathrm{z}): 390[\mathrm{M}]^{+}, 222\left[\mathrm{M}^{+}-\mathrm{C}_{12} \mathrm{H}_{25}+\mathrm{H}\right] ; \operatorname{ESIMS}(\mathrm{m} / \mathrm{z})$ : $418[\mathrm{M}]^{-}, 249\left[\mathrm{M}^{-}-\mathrm{C}_{12} \mathrm{H}_{25}\right]$; HRMS-ESI $(\mathrm{m} / \mathrm{z}):[\mathrm{M}]^{+}$calcd for $\mathrm{C}_{24} \mathrm{H}_{44} \mathrm{~N}_{3} \mathrm{O}^{+}, 390.3479$; found, 390.3484; HRMS-ESI $(\mathrm{m} / \mathrm{z})$ : $[\mathrm{M}]^{-}$calcd for $\mathrm{C}_{19} \mathrm{H}_{32} \mathrm{NO}_{5} \mathrm{~S}_{2}{ }^{-}, 418.1716$; found, 418.1791; Anal. calcd for $\mathrm{C}_{43} \mathrm{H}_{76} \mathrm{~N}_{4} \mathrm{O}_{6} \mathrm{~S}$ : C, 63.82; $\mathrm{H}, 9.47$; , 6.92; found: C, 63.83; H, 9.38; N, 6.94; DSC: $\mathrm{Cr} 93{ }^{\circ} \mathrm{C}$ [59.1 kJ mol$\left.{ }^{-1}\right] \mathrm{I}$.

\section{General procedure for the preparation of tetramethylguanidinium ion pairs $(3 \mathbf{a}, \mathbf{b})$}

A mixture of guanidinium chloride $(7 \cdot \mathrm{Cl}, 50 \mathrm{mg}, 0.122 \mathrm{mmol})$ and sulfonimide $\mathrm{K}^{+}$-salt $\mathbf{6 a}$ or $\mathbf{6 b}(0.129 \mathrm{mmol})$ in acetonitrile $(10 \mathrm{~mL})$ was heated under reflux for $5 \mathrm{~min}$. The solvent was removed under reduced pressure, the residue was taken up in dichloromethane $(20 \mathrm{~mL})$, and the slurry was filtered with a Rotilabo-syringe filter. After removal of all volatiles in vacuo, the residue was recrystallized from ethyl acetate to give the pure salts $\mathbf{3 a}, \mathbf{b}$.

$N$-(4-(Dodecyloxy)phenyl)- $N, N,, N$, $N$ "-tetramethylguanidinium ((4-(dodecyloxy)phenyl)sulfonyl)((trifluoromethyl)sulfonyl)amide (3a): Yield: $95 \mathrm{mg}$ (77\%), colorless solid; ${ }^{1} \mathrm{H}$ NMR $\left(500 \mathrm{MHz}, \mathrm{CDCl}_{3}\right) \delta 0.88(\mathrm{t}, J=7.0 \mathrm{~Hz}, 6 \mathrm{H}$, $\left.\mathrm{CH}_{3}\right), 1.20-1.39\left(\mathrm{~m}, 32 \mathrm{H}, \mathrm{CH}_{2}\right), 1.40-1.49\left(\mathrm{~m}, 4 \mathrm{H}, \mathrm{CH}_{2}\right)$, 1.73-1.82 (m, 4H, $\left.\mathrm{OCH}_{2} \mathrm{CH}_{2}\right), 2.98$ (br s, $\left.12 \mathrm{H}, \mathrm{N}\left(\mathrm{CH}_{3}\right)_{2}\right), 3.92$ (t, $\left.J=6.6 \mathrm{~Hz}, 2 \mathrm{H}, \mathrm{OCH}_{2}\right), 3.97\left(\mathrm{t}, J=6.6 \mathrm{~Hz}, 2 \mathrm{H}, \mathrm{OCH}_{2}\right.$ ),
6.85-6.91 (m, 4H, 3-H, 3"-H), 6.95-7.00 (m, 2H, 2-H), 7.85-7.90 (m, 2H, 2"-H) ppm; ${ }^{13} \mathrm{C}$ NMR (125 MHz, $\left.\mathrm{CDCl}_{3}\right) \delta$ $14.1\left(\mathrm{CH}_{3}\right), 22.7,25.99,26.04,29.13,29.24,29.36,29.39$, 29.42, 29.57, 29.59, 29.61, 29.64, 29.67, $31.9\left(\mathrm{CH}_{2}\right), 40.3$ $\left(\mathrm{N}\left(\mathrm{CH}_{3}\right)_{2}\right), 66.3,66.4\left(\mathrm{OCH}_{2}\right), 113.9(\mathrm{C}-3$ ” $), 115.7(\mathrm{C}-3), 122.3$ (C-2), 128.7 (C-2”), 130.2 (C-1), 135.6 (C-1”), 157.0 (C-4), 159.1 (C-4"), 161.6 (C-1') ppm; ${ }^{19} \mathrm{~F}$ NMR (235 MHz, $\left.\mathrm{CDCl}_{3}\right) \delta$ -78.1 ( $\left.\mathrm{CF}_{3}\right)$ ppm; FTIR (ATR) $\tilde{v}: 2917(\mathrm{~s}), 2850(\mathrm{~m}), 1620$ (m), $1595(\mathrm{~m}), 1572(\mathrm{~m}), 1512(\mathrm{~m}), 1474(\mathrm{~m}), 1423(\mathrm{w}), 1403$ (m), $1335(\mathrm{~s}), 1311(\mathrm{~m}), 1296(\mathrm{~m}), 1257(\mathrm{~m}), 1241(\mathrm{~m}), 1223$ (m), $1195(\mathrm{~s}), 1163(\mathrm{~s}), 1137(\mathrm{~s}), 1111(\mathrm{w}), 1091(\mathrm{~m}), 1032(\mathrm{vs})$, $915(\mathrm{w}), 828(\mathrm{~s}), 782(\mathrm{~m}), 752(\mathrm{~m}), 723(\mathrm{~m}), 685(\mathrm{~m}), 640(\mathrm{~m})$, $598(\mathrm{~s}), 562(\mathrm{~s}) \mathrm{cm}^{-1}$; ESIMS $(\mathrm{m} / \mathrm{z}): 376[\mathrm{M}]^{+}, 331\left[\mathrm{M}^{+}-\right.$ $\left.\mathrm{C}_{2} \mathrm{H}_{6} \mathrm{~N}-\mathrm{H}\right]$; $\operatorname{ESIMS}(\mathrm{m} / \mathrm{z}): 472[\mathrm{M}]^{-}, 303\left[\mathrm{M}^{-}-\mathrm{C}_{12} \mathrm{H}_{25}\right]$; HRMS-ESI $(\mathrm{m} / \mathrm{z})$ : $[\mathrm{M}]^{+}$calcd for $\mathrm{C}_{23} \mathrm{H}_{42} \mathrm{~N}_{3} \mathrm{O}^{+}, 376.3322$; found: 376.3334; HRMS-ESI $(\mathrm{m} / \mathrm{z})$ : $[\mathrm{M}]^{-}$calcd for $\mathrm{C}_{19} \mathrm{H}_{29} \mathrm{~F}_{3} \mathrm{NO}_{5} \mathrm{~S}_{2}{ }^{-}$, 472.1434; found, 472.1425; Anal. calcd for $\mathrm{C}_{42} \mathrm{H}_{71} \mathrm{~F}_{3} \mathrm{~N}_{4} \mathrm{O}_{6} \mathrm{~S}_{2}$ (849.2): C, 59.41; $\mathrm{H}, 8.43 ; \mathrm{N}, 6.60$; found: $\mathrm{C}$, 59.53; H, 8.36; N, 6.60; DSC: $\mathrm{Cr}_{1} 8{ }^{\circ} \mathrm{C}\left[18.6 \mathrm{~kJ} \mathrm{~mol}^{-1}\right] \mathrm{Cr}_{2}$ $19{ }^{\circ} \mathrm{C}\left[0.8 \mathrm{~kJ} \mathrm{~mol}^{-1}\right] \mathrm{Cr}_{3} 37{ }^{\circ} \mathrm{C}\left[-44.9 \mathrm{~kJ} \mathrm{~mol}^{-1}\right] \mathrm{Cr}_{4} 75{ }^{\circ} \mathrm{C}$ $\left[48.6 \mathrm{~kJ} \mathrm{~mol}^{-1}\right] \mathrm{I}$.

$N$-(4-(Dodecyloxy)phenyl)- $N^{\prime}, N^{\prime}, N^{\prime}, N^{\prime \prime}$-tetramethylguanidinium ((4-(dodecyloxy)phenyl)sulfonyl)(methylsulfonyl)amide (3b): Yield: $93 \mathrm{mg}$ (96\%); colorless solid; ${ }^{1} \mathrm{H} \mathrm{NMR}\left(500 \mathrm{MHz}, \mathrm{CDCl}_{3}\right) \delta 0.88\left(\mathrm{t}, J=6.9 \mathrm{~Hz}, 6 \mathrm{H}, \mathrm{CH}_{3}\right)$, 1.20-1.39 (m, 32H, CH 2$), 1.40-1.48\left(\mathrm{~m}, 4 \mathrm{H}, \mathrm{CH}_{2}\right), 1.72-1.81$ $\left(\mathrm{m}, 4 \mathrm{H}, \mathrm{OCH}_{2} \mathrm{CH}_{2}\right), 2.86-3.08\left(\mathrm{~m}, 12 \mathrm{H}, \mathrm{N}\left(\mathrm{CH}_{3}\right)_{2}\right), 2.90(\mathrm{~s}, 3 \mathrm{H}$, $\left.\mathrm{SO}_{2} \mathrm{CH}_{3}\right), 3.92\left(\mathrm{t}, J=6.5 \mathrm{~Hz}, 2 \mathrm{H}, \mathrm{OCH}_{2}\right), 3.96(\mathrm{t}, J=6.6 \mathrm{~Hz}$, $\left.2 \mathrm{H}, \mathrm{OCH}_{2}\right), 6.83-6.89(\mathrm{~m}, 4 \mathrm{H}, 3-\mathrm{H}, 3$ "'- $), 6.96-7.02(\mathrm{~m}, 2 \mathrm{H}$, 2-H), 7.85-7.90 (m, 2H, 2"-H) ppm; ${ }^{13} \mathrm{C}$ NMR (125 MHz, $\left.\mathrm{CDCl}_{3}\right) \delta 14.1\left(\mathrm{CH}_{3}\right), 22.7,26.0,26.1,29.16,29.25,29.36$, 29.40, 29.42, 29.58, 29.59, 29.61, 29.64, 29.67, $31.9\left(\mathrm{CH}_{2}\right)$,

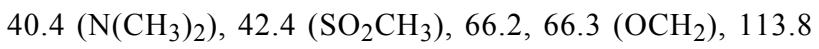
(C-3”), 115.6 (C-3), 122.2 (C-2), 128.7 (C-2”), 130.7 (C-1), 136.7 (C-1”), 156.8 (C-4), 159.2 (C-4”), 161.1 (C-1') ppm; FTIR (ATR) $\tilde{v}: 2915(\mathrm{~s}), 2850(\mathrm{~m}), 1631(\mathrm{~m}), 1597(\mathrm{~m}), 1567$ (s), $1513(\mathrm{~m}), 1467$ (m), 1434 (m), 1417 (m), 1401 (m), 1301 (w), 1271 (s), 1239 (s), 1170 (w), 1114 (s), 1079 (vs), 1061 (s), $1004(\mathrm{~m}), 972(\mathrm{~m}), 913(\mathrm{w}), 835$ (s), $800(\mathrm{~m}), 714(\mathrm{~s}) \mathrm{cm}^{-1}$; $\operatorname{ESIMS~}(\mathrm{m} / \mathrm{z}): 376[\mathrm{M}]^{+}, 331\left[\mathrm{M}^{+}-\mathrm{C}_{2} \mathrm{H}_{6} \mathrm{~N}-\mathrm{H}\right] ; \operatorname{ESIMS}(\mathrm{m} / \mathrm{z})$ : $418[\mathrm{M}]^{-}, 249\left[\mathrm{M}^{-}-\mathrm{C}_{12} \mathrm{H}_{25}\right]$; HRMS-ESI $(\mathrm{m} / \mathrm{z}):[\mathrm{M}]^{+}$calcd for $\mathrm{C}_{23} \mathrm{H}_{42} \mathrm{~N}_{3} \mathrm{O}^{+}, 376.3322$; found, 376.3331; HRMS-ESI $(\mathrm{m} / \mathrm{z})$ : $[\mathrm{M}]^{-}$calcd for $\mathrm{C}_{19} \mathrm{H}_{32} \mathrm{NO}_{5} \mathrm{~S}_{2}{ }^{-}, 418.1716$; found, 418.1724; Anal. calcd for $\mathrm{C}_{42} \mathrm{H}_{74} \mathrm{~N}_{4} \mathrm{O}_{6} \mathrm{~S}_{2}$ (795.2): C, 63.44; $\mathrm{H}$, 9.38; N, 7.05; found: C, 63.55; H, 9.31; N, 7.07; DSC: $\mathrm{Cr}_{1} 5{ }^{\circ} \mathrm{C}$ $\left[8.1 \mathrm{~kJ} \mathrm{~mol}^{-1}\right] \mathrm{Cr}_{2} 27{ }^{\circ} \mathrm{C}\left[-54.4 \mathrm{~kJ} \mathrm{~mol}^{-1}\right] \mathrm{Cr}_{3} 71{ }^{\circ} \mathrm{C}$ $\left[73.1 \mathrm{~kJ} \mathrm{~mol}^{-1}\right] \mathrm{SmA} 87^{\circ} \mathrm{C}\left[1.4 \mathrm{~kJ} \mathrm{~mol}^{-1}\right] \mathrm{I}$.

$N$-(4-(Dodecyloxy)phenyl)- $N^{\prime}, N^{\prime}, N^{\prime}, N^{\prime}$-tetramethylguanidinium iodide $(\mathbf{7} \cdot \mathrm{I})$ : A mixture of guanidinium chloride $(7 \cdot \mathrm{Cl}$, 
$400 \mathrm{mg}, 971 \mu \mathrm{mol})$ and potassium iodide (493 mg, $2.97 \mathrm{mmol}$ ) in acetonitrile $(15 \mathrm{~mL})$ was heated under reflux for $5 \mathrm{~min}$. After being cooled to room temperature, the solvent was removed under reduced pressure. The residue was taken up in dichloromethane $(20 \mathrm{~mL})$, and the resulting slurry was filtered After evaporation of the filtrate to dryness the residue was recrystallized from ethyl acetate/acetonitrile (20:1). Yield: $446 \mathrm{mg}$ (94\%); colorless solid; ${ }^{1} \mathrm{H}$ NMR $\left(500 \mathrm{MHz}, \mathrm{CDCl}_{3}\right) \delta$ $0.88\left(\mathrm{t}, J=6.9 \mathrm{~Hz}, 3 \mathrm{H}, \mathrm{CH}_{3}\right), 1.73-1.80\left(\mathrm{~m}, 2 \mathrm{H}, \mathrm{OCH}_{2} \mathrm{CH}_{2}\right)$, 2.98 (br s, $\left.12 \mathrm{H}, \mathrm{N}\left(\mathrm{CH}_{3}\right)_{2}\right), 3.91\left(\mathrm{t}, J=6.6 \mathrm{~Hz}, 2 \mathrm{H}, \mathrm{OCH}_{2}\right)$, 6.84-6.91 (m, 2H, 3-H), 7.11-7.17 (m, 2H, 3-H), 9.93 (s, 1H, $\mathrm{NH}) \mathrm{ppm} ;{ }^{13} \mathrm{C} \mathrm{NMR}\left(125 \mathrm{MHz}, \mathrm{CDCl}_{3}\right) \delta 14.1\left(\mathrm{CH}_{3}\right), 22.7$, 26.0, 29.22, 29.36, 29.41, 29.58, 29.61, 29.64, 29.67, 31.9 $\left(\mathrm{CH}_{2}\right), 41.0$ (br s, $\left.\mathrm{N}\left(\mathrm{CH}_{3}\right)_{2}\right), 68.4\left(\mathrm{OCH}_{2}\right), 115.6(\mathrm{C}-3), 122.6$ (C-2), 129.8 (C-1), 157.1, 158.4 (C-4, C-1) ppm; FTIR (ATR) $\tilde{v}: 2917$ (s), 2847 (m), 1620 (s), 1558 (s), 1510 (s), 1467 (s), $1452(\mathrm{~m}), 1417(\mathrm{~s}), 1398(\mathrm{~s}), 1312(\mathrm{~m}), 1261$ (m), $1229(\mathrm{~s})$, $1167(\mathrm{~m}), 1115(\mathrm{~m}), 1067(\mathrm{~m}), 1024(\mathrm{~m}), 1000(\mathrm{~m}), 907(\mathrm{w})$, $837(\mathrm{~s}), 798(\mathrm{w}), 782(\mathrm{w}), 719(\mathrm{~m}), 683(\mathrm{~s}), 635(\mathrm{~m}), 603(\mathrm{~m})$, $537(\mathrm{~m}) \mathrm{cm}^{-1}$; $\operatorname{ESIMS}(\mathrm{m} / \mathrm{z}): 376[\mathrm{M}]^{+}, 331\left[\mathrm{M}^{+}-\mathrm{C}_{2} \mathrm{H}_{6}-\mathrm{H}\right]$; ESIMS $(\mathrm{m} / \mathrm{z}): 127 \mathrm{[M}^{-}$; HRMS-ESI $(\mathrm{m} / \mathrm{z}):[\mathrm{M}]^{+}$calcd for $\mathrm{C}_{23} \mathrm{H}_{42} \mathrm{~N}_{3} \mathrm{O}^{+}$, 376.3323; found, 376.3343; Anal. calcd for $\mathrm{C}_{23} \mathrm{H}_{42} \mathrm{IN}_{3} \mathrm{O}$ (503.5): C, 54.86; H, 8.41; N, 8.35; found: C, 54.91; H, 8.23; N, 7.97; DSC: $\mathrm{Cr}_{1} 55^{\circ} \mathrm{C}\left[-44.3 \mathrm{~kJ} \mathrm{~mol}^{-1}\right] \mathrm{Cr}_{2}$ $130{ }^{\circ} \mathrm{C}\left[37.2 \mathrm{~kJ} \mathrm{~mol}^{-1}\right] \mathrm{I}$.

\section{Supporting Information}

\section{Supporting Information File 1 \\ DSC traces of compounds $\mathbf{2 a}, \mathbf{b}, \mathbf{3 a}$ and X-ray data of compound $\mathbf{3 b}$. \\ [http://www.beilstein-journals.org/bjoc/content/ supplementary/1860-5397-9-121-S1.pdf]}

\section{Acknowledgements}

Generous financial support by the Studienstiftung des Deutschen Volkes (Fellowship for M.B.), the Deutsche Forschungsgemeinschaft, the Ministerium für Wissenschaft, Forschung und Kunst des Landes Baden-Württemberg, the Fonds der Chemischen Industrie and the Forschungsfonds der Universität Stuttgart is gratefully acknowledged.

\section{References}

1. Endres, F.; MacFarlane, D.; Abbott, A. P., Eds. Electrodeposition from Ionic Liquids; Wiley-VCH: Weinheim, Germany, 2008. doi:10.1002/9783527622917

2. Ionic Liquids IIIA: Fundamentals, Progress, Challenges, and Opportunities; Seddon, K. R.; Rogers, R. D., Eds.; ACS Symposium Series, Vol. 901; American Chemical Society: Washington, 2005. doi:10.1021/bk-2005-0901
3. Ionic Liquids IIIB: Fundamentals, Progress, Challenges, and Opportunities-Transformations and Processes; Seddon, K. R.; Rogers, R. D., Eds.; ACS Symposium Series, Vol. 902; American Chemical Society: Washington, 2005. doi:10.1021/bk-2005-0902

4. Wasserscheid, P.; Welton, T., Eds. Ionic Liquids in Synthesis, 2nd ed.; Wiley-VCH: Weinheim, Germany, 2008. doi:10.1002/9783527621194

5. Dupont, J.; de Souza, R. F.; Suarez, P. A. Z. Chem. Rev. 2002, 102, 3667-3692. doi:10.1021/cr010338r

6. Axenov, K. V.; Laschat, S. Materials 2011, 4, 206-259. doi:10.3390/ma4010206

7. Kato, T.; Mizoshita, N.; Kishimoto, K. Angew. Chem. 2006, 118, 44-74. doi:10.1002/ange.200501384

Angew. Chem., Int. Ed. 2006, 45, 38-68. doi:10.1002/anie.200501384

8. Binnemans, K. Chem. Rev. 2005, 105, 4148-4204. doi:10.1021/cr0400919

9. Heintz, W. Justus Liebigs Ann. Chem. 1854, 92, 291-299. doi:10.1002/jlac.18540920306

10. Heintz, W. J. Prakt. Chem. 1855, 66, 1-51. doi:10.1002/prac.18550660101

11. Knight, G. A.; Shaw, B. D. J. Chem. Soc. 1938, 682-683. doi:10.1039/jr9380000682

12. Somashekar, R. Mol. Cryst. Liq. Cryst. 1987, 146, 225-233. doi:10.1080/00268948708071815

13. Bowlas, C. J.; Bruce, D. W.; Seddon, K. R. Chem. Commun. 1996, 1625-1626. doi:10.1039/cc9960001625

14. Jákli, A.; Saupe, A. One- and Two-Dimensional Fluids: Properties of Smectic, Lamellar and Columnar Liquid Crystals; CRC Press: Boca Raton, 2006. doi:10.1201/9781420012200

15. Welton, T. Chem. Rev. 1999, 99, 2071-2084. doi:10.1021/cr980032t

16. Plechkova, N. V.; Seddon, K. R. Chem. Soc. Rev. 2008, 37, 123-150. doi:10.1039/b006677j

17. Bonhôte, P.; Dias, A.-P.; Papageorgiou, N.; Kalyanasundaram, K.; Grätzel, M. Inorg. Chem. 1996, 35, 1168-1175. doi:10.1021/ic951325x

18. Jacquemin, J.; Husson, P.; Padua, A. A. H.; Majer, V. Green Chem. 2006, 8, 172-180. doi:10.1039/b513231b

19. Keskin, S.; Kayrak-Talay, D.; Akman, U.; Hortaçsu, Ö. J. Supercrit. Fluids 2007, 43, 150-180. doi:10.1016/j.supflu.2007.05.013

20. Johansson, K. M.; Adebahr, J.; Howlett, P. C.; Forsyth, M.; MacFarlane, D. R. Aust. J. Chem. 2007, 60, 57-63. doi:10.1071/CH06299

21. Hickman, T.; DesMarteau, D. D. J. Fluorine Chem. 2012, 133, 11-15. doi:10.1016/j.jluchem.2011.11.001

22. Gao, Y.; Slattery, J. M.; Bruce, D. W. New J. Chem. 2011, 35 , 2910-2918. doi:10.1039/c1nj20715f

23. Bhowmik, P. K.; Han, H.; Cebe, J. J.; Nedeltchev, I. K. Polym. Prepr. (Am. Chem. Soc., Div. Polym. Chem.) 2002, 43, 1385-1386.

24. Bhowmik, P. K.; Han, H.; Cebe, J. J.; Burchett, R. A.; Acharya, B.; Kumar, S. Liq. Cryst. 2003, 30, 1433-1440. doi:10.1080/02678290310001621895

25. Bhowmik, P. K.; Han, H.; Nedeltchev, I. K.; Cebe, J. J. Mol. Cryst. Liq. Cryst. 2004, 419, 27-46. doi:10.1080/15421400490478272

26. Causin, V.; Saielli, G. J. Mater. Chem. 2009, 19, 9153-9162. doi:10.1039/b915559g

27. Jo, T. S.; Wray, J. K.; Tanthmanatham, O.; Han, H.; Bhowmik, P. K. Polym. Prepr. (Am. Chem. Soc., Div. Polym. Chem.) 2011, 52, 387-388. 
28. Bonchio, M.; Carraro, M.; Casella, G.; Causin, V.; Rastrelli, F.; Saielli, G. Phys. Chem. Chem. Phys. 2012, 14, 2710-2717. doi:10.1039/c2cp23580c

29. Fernandez, A. A.; de Haan, L. T.; Kouwer, P. H. J. J. Mater. Chem. A 2013, 1, 354-357. doi:10.1039/c2ta00133k

30. Alam, M. A.; Motoyanagi, J.; Yamamoto, Y.; Fukushima, T.; Kim, J.; Kato, K.; Takata, M.; Saeki, A.; Seki, S.; Tagawa, S.; Aida, T. J. Am. Chem. Soc. 2009, 131, 17722-17723. doi:10.1021/ja905373d

31. Goossens, K.; Nockemann, P.; Driesen, K.; Goderis, B.; Görller-Walrand, C.; Van Hecke, K.; Van Meervelt, L.; Pouzet, E.; Binnemans, K.; Cardinaels, T. Chem. Mater. 2008, 20, 157-168. doi:10.1021/cm702321c

32. Goossens, K.; Lava, K.; Nockemann, P.; Van Hecke, K.; Van Meervelt, L.; Pattison, P.; Binnemans, K.; Cardinaels, T. Langmuir 2009, 25, 5881-5897. doi:10.1021/la900048h

33. Goossens, K.; Lava, K.; Nockemann, P.; Van Hecke, K.; Van Meervelt, L.; Driesen, K.; Görller-Walrand, C.; Binnemans, K.; Cardinaels, T. Chem.-Eur. J. 2009, 15, 656-674. doi:10.1002/chem.200801566

34. Bhowmik, P. K.; Han, H.; Cebe, J. J.; Burchett, R. A.; Sarker, A. M. J. Polym. Sci., Part A: Polym. Chem. 2002, 40, 659-674. doi:10.1002/pola.10134

35. Bhowmik, P. K.; Han, H.; Cebe, J. J.; Nedeltchev, I. K.; Kang, S.-W.; Kumar, S. Macromolecules 2004, 37, 2688-2694. doi:10.1021/ma030460n

36. Bhowmik, P. K.; Han, H.; Nedeltchev, A. K. J. Polym. Sci., Part A: Polym. Chem. 2006, 44, 1028-1041. doi:10.1002/pola.21181

37. Han, H.; Vantine, P. R.; Nedeltchev, A. K.; Bhowmik, P. K. J. Polym. Sci., Part A: Polym. Chem. 2006, 44, 1541-1554. doi:10.1002/pola.21259

38. Butschies, M.; Frey, W.; Laschat, S. Chem.-Eur. J. 2012, 18, 3014-3022. doi:10.1002/chem.201101925

39. Lo Celso, F.; Pibiri, I.; Triolo, A.; Triolo, R.; Pace, A.; Buscemi, S.; Vivona, N. J. Mater. Chem. 2007, 17, 1201-1208. doi:10.1039/B615190F See for example for ILCs with trifluoromethanesulfonate counterion.

40. El Kadib, A.; Hesemann, P.; Molvinger, K.; Brandner, J.; Biolley, C.; Gaveau, P.; Moreau, J. J. E.; Brunel, D. J. Am. Chem. Soc. 2009, 131, 2882-2892. doi:10.1021/ja807630j

41. Jones, P. B.; Parrish, N. M.; Houston, T. A.; Stapon, A.; Bansal, N. P.; Dick, J. D.; Townsend, C. A. J. Med. Chem. 2000, 43, 3304-3314. doi:10.1021/jm000149l

42. Sauer, S.; Saliba, S.; Tussetschläger, S.; Baro, A.; Frey, W.; Giesselmann, F.; Laschat, S.; Kantlehner, W. Liq. Cryst. 2009, 36, 275-299. doi:10.1080/02678290902850027

43. Marcus, Y. J. Chem. Soc., Faraday Trans. 1993, 89, 713-718. doi:10.1039/ft9938900713

44. Schulz, T.; Ahrens, S.; Meyer, D.; Allolio, C.; Peritz, A.; Strassner, T. Chem.-Asian J. 2011, 6, 863-867. doi:10.1002/asia.201000744

45. Ahrens, S.; Peritz, A.; Strassner, T. Angew. Chem. 2009, 121, 8048-8051. doi:10.1002/ange.200903399 Angew. Chem., Int. Ed. 2009, 48, 7908-7910. doi:10.1002/anie.200903399

\section{License and Terms}

This is an Open Access article under the terms of the Creative Commons Attribution License

(http://creativecommons.org/licenses/by/2.0), which permits unrestricted use, distribution, and reproduction in any medium, provided the original work is properly cited.

The license is subject to the Beilstein Journal of Organic Chemistry terms and conditions:

(http://www.beilstein-journals.org/bjoc)

The definitive version of this article is the electronic one which can be found at:

doi:10.3762/bjoc.9.121 